\title{
Women in situations of sexual violence: potentialities and weaknesses of the intersectoral network
}

\author{
Mulheres em situação de violência sexual: potencialidades e fragilidades da rede intersetorial \\ Mujeres en situaciones de violencia sexual: potencialidades y debilidades de la red intersectorial
}

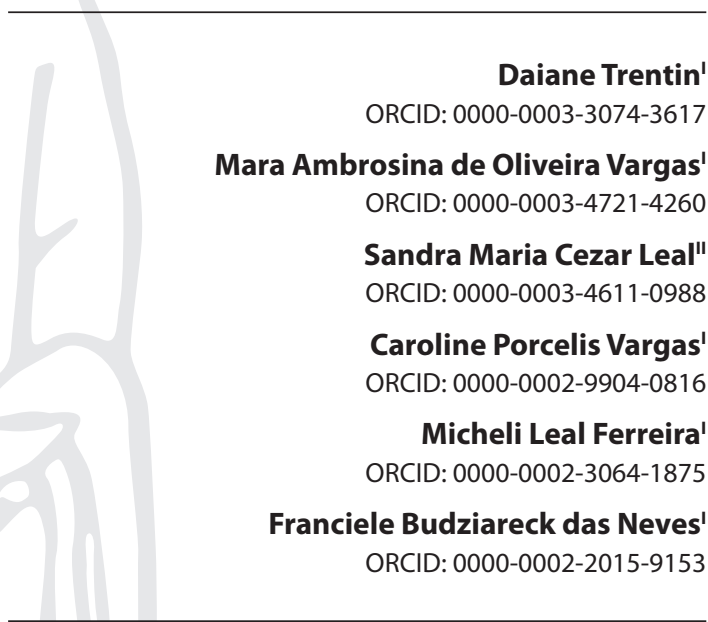

'Universidade Federal de Santa Catarina. Florianópolis, Santa Catarina, Brazil. "Universidade do Vale do Rio dos Sinos. Porto Alegre, Rio Grande do Sul, Brazil.

How to cite this article: Trentin D, Vargas MAO, Leal SMC, Vargas CP, Ferreira ML, Neves FB. Women in situations of sexual violence: potentialities and weaknesses of the intersectoral network. Rev Bras Enferm. 2020;73(4):e20190856. doi: http://dx.doi.org/10.1590/0034-7167-2018-0856

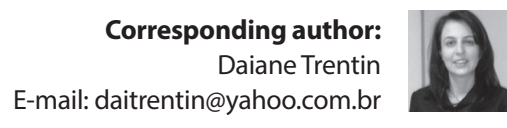

EDITOR IN CHIEF: Antonio José de Almeida Filho ASSOCIATE EDITOR: Cristina Parada

Submission: 03-23-2019

Approval: 09-14-2019

\section{ABSTRACT}

Objectives: to identify potentialities and weaknesses of the intersectoral network for women in situations of sexual violence, from the perspective of Intervention Bioethics and the Universal Declaration on Bioethics and Human Rights. Methods: qualitative study conducted with multidisciplinary team members who work in intersectoral care services for women subject to sexual violence. It was held in a municipality in southern Brazil. An intentional sample, totaling 30 professionals. Semi-structured interview was used from January to April 2016. Interviews were analyzed by Thematic Analysis. Results: two categories emerged: potentialities and weaknesses related to the intersectoral network. Potentialities confirm the importance of the articulated intersectoral network; weaknesses such as lack of organized flow and disarticulation of services result in women revictimization and care fragmentation. Final Considerations: it is necessary to articulate services and qualify professionals. The Intervention Bioethics and the Universal Declaration on Bioethics and Human Rights foster discussions that contribute to how to organize and sustain the intersectoral network.

Descriptors: Violence Against Women; Sex Offenses; Patient Care Team; Intersectoral Collaboration; Bioethics.

\section{RESUMO}

Objetivos: identificar potencialidades e fragilidades da rede intersetorial à mulher em situação de violência sexual, na perspectiva da Bioética de Intervenção e da Declaração Universal sobre Bioética e Direitos Humanos. Métodos: estudo qualitativo, realizado com membros da equipe multiprofissional que atuam nos serviços intersetoriais de atendimento à mulher em situação de violência sexual (munícipio no Sul do Brasil). Amostra intencional, totalizando 30 profissionais. A técnica de coleta foi a entrevista semiestruturada, de janeiro a abril de 2016. Entrevistas analisadas pela análise temática. Resultados: emergiram duas categorias: potencialidades e fragilidades relacionadas a rede intersetorial. Potencialidades confirmam a importância da rede intersetorial articulada, fragilidades, como falta de fluxo organizado e desarticulação dos serviços, resultam na revitimização da mulher e fragmentação do cuidado. Considerações Finais: necessário articular os serviços e qualificar os profissionais. A Bioética de Intervenção e a Declaração Universal sobre Bioética e Direitos Humanos fomentam discussões que contribuem no modo de organizar e sustentar a rede intersetorial.

Descritores: Violência Contra a Mulher; Delitos Sexuais; Equipe de Assistência ao Paciente; Colaboração Intersetorial; Bioética.

\section{RESUMEN}

Objetivos: identificar las potencialidades y debilidades de la red intersectorial para mujeres em situaciones de violencia sexual, desde la perspectiva de la Intervención Bioética y la Declaración Universal de Bioética y Derechos Humanos. Métodos: este es un estudio cualitativo realizado con miembros del equipo multiprofesional que trabajan em servicios de atención intersectorial para mujeres em situaciones de violencia sexual (municipio em el sur de Brasil). La muestra fue intencional, totalizando 30 profesionales. La técnica de recolección fue la entrevista semiestructurada, de enero a abril de 2016. Las entrevistas fueron analizadas por análisis temático. Resultados: surgieron dos categorías: potencialidades y debilidades relacionadas con la red intersectorial. Las potencialidades confirman la importancia de la red intersectorial articulada, las debilidades, como la falta de flujo organizado y la desarticulación de los servicios, dan como resultado la revictimización de las mujeres y la fragmentación de la atención. Consideraciones Finales: es necesario articular los servicios y calificar a los profesionales. La Intervención Bioética y la Declaración Universal de Bioética y Derechos Humanos fomentan debates que contribuyen a cómo organizar y mantener la red intersectorial.

Descriptores: Violencia Contra la Mujer; Delitos Sexuales; Grupo de Atención al Paciente; Colaboración Intersectorial; Bioética. 


\section{INTRODUCTION}

Comprehensiveness and the intersectoral network established and articulated is a potential in care for women in situations of sexual violence ${ }^{(1-2)}$. Among the minimum requirements in responding to situations of violence against women are public policies and protocols, manager support and financial resources, comprehensive care and intersectoral collaboration stout ${ }^{(3)}$.

In Brazil, Violence against Women Coping Network (Rede de Enfrentamento à Violência contra as Mulheres) stands out. It includes Care Network, which includes full care of different services such as social assistance, justice, public safety and health for women subjected to violence ${ }^{(4)}$. Particularly related to sexual violence, Ordinance MoH/Minister's Office 485 of April 1, 2014, which redefines the Care Service for People Subjected to Sexual Violence (Serviço de Atenção às Pessoas em Situação de Violência Sexual) operation within the SUS (Sistema Único de Saúde - Brazilian Health System) $)^{(5)}$, in article 2 of that Ordinance, stresses that:

The Care Service for People Subjected to Sexual Violence within the SUS scope integrates the intersectoral networks to cope with violence against women, men, children, adolescents and the elderly. Its main functions are to preserve life, provide comprehensive health care and foster networked $\operatorname{car}^{(5)}$.

The importance of health services in the intersectoral network is emphasized in one of the recent documents published by the World Health Organization (WHO). This document presents a manual for health managers to strengthen health services in care for women subjected to gender-based violence perpetrated by intimate partners or sexual violence ${ }^{(1)}$. Among other points, the manual signals health services as facilitators for women in accessing other services in the intersectoral network. It also signs respect for women's human rights, one of the fundamental principles guiding care, and benefits of the built and articulated intersectoral network ${ }^{(1)}$.

In the context of health professionals, the reality shows inconsistencies between what is prescribed in the norms and daily practice of care in situations of violence. Studies indicate weaknesses in the intersectoral network, such as disarticulation of services and lack of knowledge of the network ${ }^{(6-7)}$; need for the network to be built and strengthened ${ }^{(8-9)}$; absence of protocols ${ }^{(10)}$; instrumentalization of the incipient professional(11-12); network access difficulty ${ }^{(9)}$. When the intersectoral network is organized and articulated, it is a potential for care ${ }^{(8,13)}$.

International studies highlight the need and importance of an integrated response, training of professionals and multisectoral strengthening to coordinate and provide resources to people affected by violence ${ }^{(14-15)}$, as well as standardized treatment protocols ${ }^{(16)}$. This evidence points to the magnitude of sexual violence, which focuses on women's suffering and the psychological, physical consequences and risks of sexually transmitted infections (STIs) among others ${ }^{(11)}$. Therefore, network articulation is indispensable to provide full technical support in women care.

In this study, Intervention Bioethics (BI) and Universal Declaration on Bioethics and Human Rights (UDBHR) contribute to the reflection of the theme of the intersectoral network to women in subjected to sexual violence. This discussion occurs because violence is a complex phenomenon and surrounded by multiple causes, requiring a set of actions and sectors in care and coping ${ }^{(17)}$, and a public health issue ${ }^{(2)}$.

IB emerges as one of the alternatives to principled bioethics, advocating policies and decisions that benefit the greatest number of people, in the longest time and with the best consequences. In 2005, the approval of UDBHR broadens the bioethical agenda of the biomedical and biotechnological area to social, sanitary and environmental areas, confirming the pluralistic character of bioethics ${ }^{(18)}$.

IB enables discussions about ethical dilemmas, the promotion of justice, protection and equity ${ }^{(19-20)}$. UDBHR contains in its text fundamental principles of bioethics, such as the right to health, human dignity and human rights. Although addressed to states, UDBHR can also guide decisions or practices of individuals, groups, public or private institutions in relevant situations ${ }^{(21)}$.

Despite the existence of studies on the intersectoral network and care for women in situations of sexual violence, our purpose is to look at the potentialities and weaknesses of the intersectoral network involving the discussion of bioethics. There are few studies that deal with this reflection.

\section{OBJECTIVES}

To identify potentialities and weaknesses of the intersectoral network for women in situations of sexual violence, from the perspective of Intervention Bioethics (IB) and the Universal Declaration on Bioethics and Human Rights (UDBHR).

\section{METHODS}

\section{Ethical aspects}

Data were collected by the researcher after approval by the Research Ethics Committee (CEPSH/UFSC) involving Human Beings. Participants who agreed to participate in the interviews were given the Free and Informed Consent Form (FICF), in two ways, explaining the objectives of the study and clarifying any doubts.

\section{Type of study}

This is an exploratory-descriptive study of qualitative approach.

\section{Study setting}

The study was conducted with multidisciplinary team members who work in intersectoral care services for women in situations of sexual violence in a municipality located in the northern region of Rio Grande do Sul state (RS). There are two hospitals, Municipal Health Secretariat (SMS) that coordinates the Specialized Care Service (SCS), Basic Health Units (BHU) and Family Health Strategy (FHS); Citizenship and Social Assistance Office (SEMCAS - Secretaria de Cidadania e Assistência Social) which coordinates the Specialized Reference Center on Social Assistance (CREAS) and Casa Abrigo; Specialized Police Station for Women Service 
(DEAM - Delegacia Especializada no Atendimento à Mulher); Public ministry; and the extension project of Universidade de Passo Fundo (UPF): Clinical Studies, Prevention, Intervention and Follow-up to Violence (CEPAVI - Clínica de Estudos, Prevenção, Intervenção e Acompanhamento à Violência).

The selected locations considered the services of the municipality where women in situations of sexual violence are able to seek care. The coordinator of the Surveillance of Noncommunicable Diseases and Diseases (DANTs) of the $6^{\text {th }}$ Regional Health Coordination (CRS - Coordenadoria Regional de Saúde) of RS and the coordinator of Health Surveillance of the municipality were the study's key informants. They informed the locations for the interviews. In choosing the BHU and FHS, the following intentionality criteria were used: two BHU and FHS indicated by the Epidemiological Surveillance Center of the municipality with the highest number of cases of sexual violence. Access to this data occurred through the Notification Disease Information System (SINAN - Sistema de Informação de Agravos de Notificação).

\section{Data source}

Study participants were members of the multidisciplinary team that work in intersectoral care services for women in situations of sexual violence in the municipality under study. The sample was intentionally composed, totaling 30 professionals. Participant selection for the interview was performed according to the inclusion criteria: higher education or technical professionals, who have assisted or assist women in situations of sexual violence, regardless of age, sex, working hours and length of work. Exclusion criteria were: professionals who were on vacation or legally removed for some type of leave.

\section{Collection and organization of data}

Data collection took place from January to April 2016. The technique used for data collection was the semi-structured interview. Of the individual interviews, 23 were recorded after participants' consent, and 7 were handwritten due to participants not authorizing the recording.

During the interviews, the following services emerged from some of survey participants: Department of Forensic Medical (DFM) and Projur Mulher Project: legal provision to women subjected to domestic and family violence (UPF's extension project). Authorization for interview was requested and, after authorization, its performance.

Contact with the indicated participants was made by telephone, with subsequent scheduling of the date and time for the interview, according to participant availability, in the workplace and ensuring privacy. The order of the data collection process was flexible and according to the situation of each location and the possibilities presented by participants.

Participants were identified with the letter $\mathrm{P}$ (professional), followed by the initial letter of their practice area: $\mathrm{H}$ - Health (hospital and public health) and PPS - Protection or Psychosocial Support (professionals working in the area of justice, public safety, social work, psychological assistance); and a number (according to the order of interviews), ensuring anonymity.

\section{Data analysis}

After transcribing the interviews in full, they were validated by participants. To assist in organizing the data, the software Atlas.ti 7.5.6 (Qualitative Research and Solutions) was used. As a material analysis technique, the Thematic Analysis ${ }^{(22)}$ was used. This technique consists of three stages: first stage (pre-analysis), second stage (material exploration) and third stage (treatment of results obtained and interpretation).

\section{RESULTS}

Participated in the study: 11 nurses, six psychologists, five doctors, three lawyers and three social workers, and other professions, two participants. Regarding the area of expertise, 12 health professionals work in the hospital area and 10 public health professionals. In the area of protection or psychosocial support, 8 professionals participated. Length of service ranged from one year to 25 years or more, with 28 higher education and two vocational training.

From the analysis of the material, the study results were divided into two categories: potentialities and weaknesses of the intersectoral network to women in situations of sexual violence. These results were organized in the Atlas.ti 7.5.6 software. Figure 1 presents the potentialities and Figure 2 the weaknesses of the intersectoral network.

\section{Potentialities}

Statements report as potentialities of the intersectoral network: the presence of support groups - which establish links with women in situations of sexual violence; services - include specialist and non-specialist care services, especially within the first 72 hours and with regard to the medication and examination protocol; professional commitment - despite the difficulties, there is a search to proceed with the relevant referrals; and the multidisciplinary team - in order to contemplate care comprehensiveness.

The following statements elucidate some of the potentialities found:

By the time she comes, she gets the necessary medication, gets the necessary tests, is called an expert, is investigated, is taken care of. (PH20)

I think groups are a potentiality. Home visits are also potential in our work, which also brings together. (PH6)

The municipality has the DEAM and hospital, which provides cuttingedge care on health issues related to this type of situation. (PPPS1)

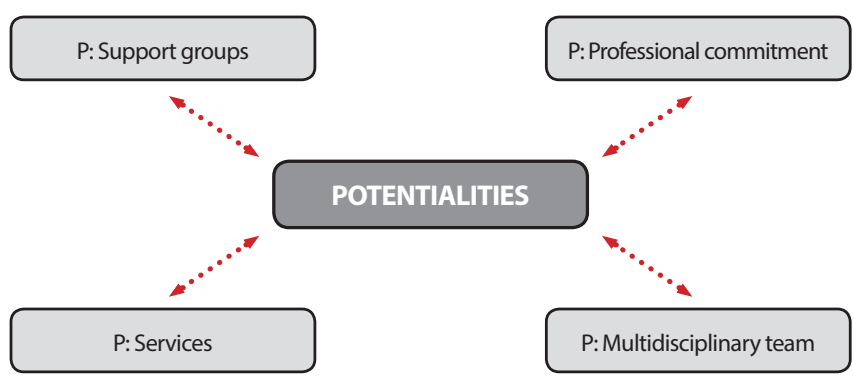

Figure 1 - Potentials of the intersectoral network 


\section{Weaknesses}

Concerning the weaknesses, the issues related to flow and disarticulation stand out - incipient articulation between the services; instrumentalization and lack of professionals - weak preparation of professionals in care and lack of some professional categories.

Other issues refer to: information - unawareness of service and flow professionals; communication - scarce exchange of information between sectors; physical structure - inadequate environments; network access - difficulties accessing services; revictimization - woman's path among disjointed services; lack of protocols - lack of protocols in some services and among sectors for service flow; and resistances - barriers imposed by professionals to address cases of sexual violence.

Some of situations pointed out are illustrated in the following statements:

As the name is saying NETWORK, it should be all interconnected, connected so that the provision of professional services that make up the network was adequate. What we have today, from my point of view: There are a number of bodies in charge of sexual violence, but we are not interconnected. (PPPS30)

There is resistance to this type of care, because it takes time, I will not know how to ask. Anyway, I have a lot of service, I have other things that are a priority, I hear that from colleagues! ( $\mathrm{PH} 24)$

I don't think there is that flow, there is no interconnection among all the institutions that work with it. If you tried to do it, you tried to organize it, but somewhere it still ended up stopping [...]. I realize that sometimes this network access is very difficult. [...] Sometimes they refer us and they end up not coming, if they lose this referral or because they can't afford to come to us, sometimes financial resources, sometimes she doesn't even have an emotional support to come. I would say the difficulties are really her first issue being able to access, because sometimes they can't reach or move here. (PPPS8)

If as a professional you have to call several places to know where to go, imagine the user knocking from door to door. It is a difficulty. I don't think you can work in a harmonious way, knowing very well: this patient I can refer to such and such places. ( $\mathrm{PH} 4)$

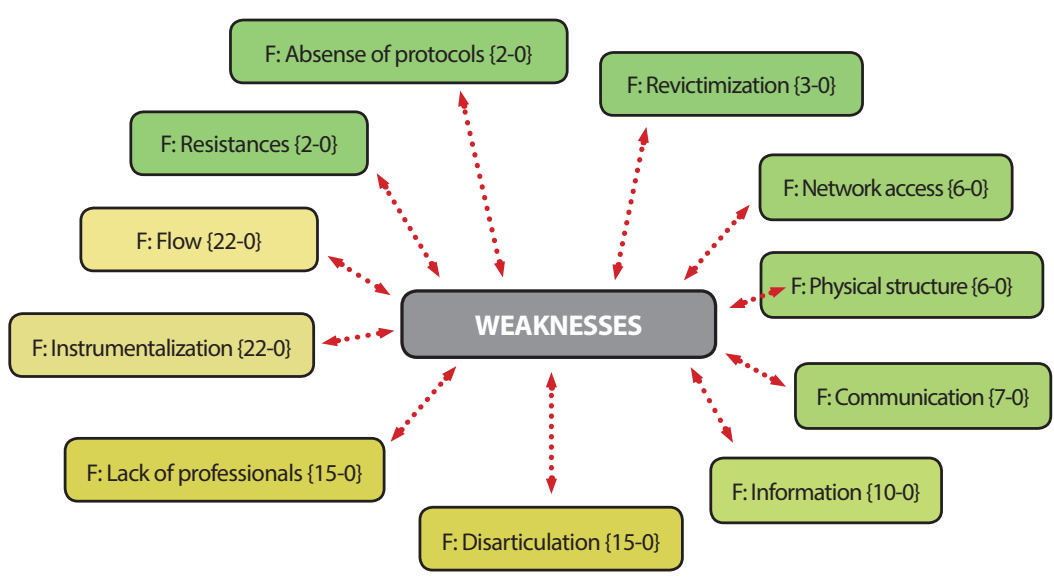

Figure 2 - Weaknesses of the intersectoral network
You introduce yourself as someone who will listen to her, you will hear that person as a source of support and often you are not even having the support necessary to meet this woman victim of violence. We professionals are often not able to serve these women victims of violence. (PH3)

We highlight the identification of more weaknesses than potentialities in the intersectoral network of women in situations of sexual violence.

\section{DISCUSSION}

In the discussion regarding the potentialities and weaknesses of the intersectoral network, the inferred analysis relates the categories that emerged from the material and the approximation with some elements of IB and UDBHR. Regarding IB, we highlight the access to services, public policies and the social dimension, as the proposal of IB considers the place from which bioethical conflicts are assessed, so health issues need to be articulated with the assessment of social conditions ${ }^{(20)}$. With regard to UDBHR, the objective of contributing to respect for human dignity and protection of human rights, such as the principle of human dignity and human rights and health promotion, is emphasized ${ }^{(21)}$.

In the category of potentialities, the mention of support groups reveals the importance of establishing links. Bonding, one of the benefits of the built and articulated intersectoral network, favors women who have experienced sexual violence care follow-up and monitoring, and also encourages them to reveal situations of violence. In this sense, a study that analyzed the social network and types of support for women subjected to intimate partner violence identifies strong bonds between women and the secondary network (in the study defined as the network constituted by official institutions), such as reception and resolute care $^{(8)}$.

Services, some specialized, such as DEAM and others nonspecialized, such as general hospitals, but which are references in care for women in situations of sexual violence, emerge in the context of the municipality as potentialities. Among the highlighted points, there is the application of the protocol of exams and medications, in which the speed of implementation of this protocol is fundamental to avoid STIs and other consequences of sexual violence ${ }^{(2)}$. Physical and gynecological examinations, serological tests, trace collection, pharmaceutical assistance and multidisciplinary follow-up are an effective means of applying legislation, guidelines and public policies. This was demonstrated in a study carried out in a Service for Women Victim of Violence in the state of Piauí, aiming to assess public policies, legislation to protect women and health care for victims of sexual violence ${ }^{(23)}$.

Professional commitment refers to the potential of professionals in the intersectoral network to overcome the difficulties encountered. Among them are the lack of some categories of professionals and the physical structure to perform the necessary care and referrals in situations of 
sexual violence. In a rural context, a study about access and accessibility to the care network highlights the potential of nursing professionals in welcoming and promoting the articulation of network services ${ }^{(9)}$. A systematic review of the literature signals potential health professionals who, in addition to care, act as a gateway to other support services ${ }^{(24)}$.

The multidisciplinary team is another potential in situations of sexual violence. Although mentioned as a potentiality, teamwork needs to be strengthened. It is one of the requirements described in $\mathrm{WHO}^{(3)}$ and Brazilian ${ }^{(2)}$ documents; qualifying and providing comprehensive care to women. Therefore, it is necessary the articulation of different knowledge to work together and focused ${ }^{(9,25)}$.

In the context of this study, the intersectoral network has potential, even if incomplete and incipient, and aims to obtain comprehensive care in situations of sexual violence, considering the dimensions and situations that involve women. Thus, it is related to the perspective of IB and UDBHR, in which health issues need to be articulated with the person's social conditions ${ }^{(20)}$, contemplating the principle of human dignity and human rights, and transcending biomedical and biotechnological issues ${ }^{(21,26)}$.

The category of weaknesses emerges with greater evidence than potentialities; with emphasis on flow and instrumentation. Professionals report the lack of organized flow, and despite the existence of services, which are potentialities in the municipality, stands out disarticulation among them. Related issues articulation in care in situations of violence are also signaled in other national contexts ${ }^{(7,10,17,27-28)}$. Internationally, a study in five countries also highlights the need for protocols and articulation among network services, as an effective response to coping with violence against women ${ }^{(6)}$.

Mentioning, in some lines, the existence of institutional flow stands out. However, within the municipality there is incipient information, inferring the absence of implemented flowchart and the disarticulation among services of the intersectoral network.

We highlight the relationship between the revictimization of women with lack of flow and disarticulation of services, in which women need to recount the fact of violence in various services or professionals who seek ${ }^{(7)}$. In this sense, flow articulation and organization, as well as the knowledge of the services that exist in the city to make the referrals, allows the professional clarity and better direction of what to do in situations of sexual violence. Thus, women's suffering and exposure to other violence can be prevented.

Weak instrumentalization is another issue that emerges. Unpreparedness of professionals due to gaps in their education about the theme, due to incipient qualification processes, has negative consequences such as inadequate approach and prejudiced practices, revitalizing women ${ }^{(9,11-12)}$. Thus, training and qualification of professionals are fundamental to improve care $\mathrm{e}^{(6,10,14-15)}$.

These incipient processes in the professional's formation and personal difficulties may be associated with the resistance of some professionals in cases of sexual violence. Violence requires care beyond the physical, involving other dimensions of the person. This can be challenging and generate the resistance to meet women. In this sense, a study indicates that there are professionals with a listening practice that does not include the subjective and social dimension of women ${ }^{(10)}$.

The lack of some categories of professionals is another weakness. This aspect refers to public managers and services in search of resolution of this need. The insufficient quantity of human resources is due to the delay in care ${ }^{(29)}$. Waiting for appointments, especially specialized, is another factor linked to the lack of professionals, which may cause the woman to give up following and monitoring, compromising care comprehensiveness.

Lack of protocols is reported by professionals in some services and within the municipality. Protocols provide standardization in care ${ }^{(16)}$. However, if on the one hand it is an instrument that helps in the organization of intersectoral actions in the network, on the other hand the use of fixed and unique actions can also restrict effective practice in care, because of the complexity of violence requiring collective solutions ${ }^{(10)}$.

Another issue that emerges is information, which concerns the professionals' lack of knowledge about the flow and the set of services available in the city for referrals, compromising the agility and quality of care. For a powerful intersectoral network, knowledge of the services involved and communication among professionals is necessary. Knowing the services enables comprehensiveness through appropriate referrals related to women's needs ${ }^{(27-28)}$. About communication, this is fundamental for the articulation of the network, which needs, besides the dialogue between services, communication and interaction among professionals ${ }^{(13)}$.

Regarding physical structure, the documents recommend welcoming spaces with appropriate structure ${ }^{(2-3)}$. However, inadequate structure, such as lack of physical space to approach women with privacy, is a weakness found by professionals and experienced by women ${ }^{(29)}$. Regarding the issue of network access, difficulties arising from logistics, information and other elements weaken access to network services. Difficulty in access to services by particular groups is demonstrated in a study of survivors of sexual violence living in poverty who analyzed the challenges and experiences in obtaining assistance. Accessibility to information and training for professionals have been found to ensure accessible services that meet the needs of survivors of sexual violence ${ }^{(30)}$.

Access and comprehensiveness of care are incipient in view of the weaknesses of the intersectoral network. From the perspective of IB, which discusses social inequalities, such as lack of access to health and emphasizes the State's responsibility to defend the most vulnerable populations, there are deficiencies in public policies ${ }^{(20-31)}$. It violates the principle of human dignity and human rights(20-21).

The implementation of public policies is a mean to overcome weaknesses in the network. A study highlights the importance of UDBHR in providing theoretical and normative tools, providing reflective and prescriptive contributions about the context of inequality, especially in health. It shows that UDBHR's principle of justice calls on states and international institutions to adopt policies designed to reconfigure the distribution of resources ${ }^{(32)}$.

\section{Study limitations}

Although the present investigation includes a relevant number of members of the multidisciplinary team who work in intersectoral care services for women in situations of sexual violence, the study aspect is identified as a study limitation. This needs to be considered in the reproduction and dissemination of results. 


\section{Contributions to nursing, health or public policy}

Care for women in situations of sexual violence, from the perspective of the network, characterizes an advance in care. Therefore, this study contributes to phenomenon exploration - intersectoral network - from the perspective of professionals, providing elements for a proposal of articulation and sustainability of the network to women in situations of sexual violence.

It must be identified the context place with its potentialities and weaknesses from the reality, to propose improvements and actions that make it possible to implement what is prescribed in the guiding documents. Articulation of services and the implemented flow, sufficiently instrumentalized professionals, enable women in situations of sexual violence to access services, comprehensive care and, as a result, ensure their rights and dignity.

\section{FINAL CONSIDERATIONS}

The study identified potentialities that confirm the importance of the instituted and articulated intersectoral network, and weaknesses, especially lack of organized flow and disarticulation of services. Issues focused on women revictimization and care fragmentation emerged. The reality of the municipality, in the perspective of professionals, indicates a way to go in the search to overcome the intersectoral network gaps. To this end, services are articulated by qualifying professionals, and financial and human resources are allocated to respond to the complexity of sexual violence.

IB and UDBHR point to the importance of public policies in achieving what is recommended in international and national documents in defense of human rights and human dignity. They provide input and foster discussions that contribute to how to organize and sustain the intersectoral network. Comprehensive care for women in situations of sexual violence needs to consider the context that surrounds them and the reality of the network in the municipality.

\section{FUNDING}

This paper was supported by the Higher Education Personnel Improvement Coordination - Brazil (CAPES - Coordenação de Aperfeiçoamento de Pessoal de Nível Superior) - Financing Code 001.

\section{REFERENCES}

1. World Health Organization (WHO). Strengthening health systems to respond to women subjected to intimate partner violence or sexual violence: a manual for health managers [Internet]. Geneva; 2017 [cited 2018 Mar 27]. Available from: http://www.who.int/ reproductivehealth/publications/violence/vaw-health-systems-manual/en//

2. Ministério da Saúde (BR), Secretaria de Atenção à Saúde, Departamento de Ações Programáticas Estratégicas. Prevenção e tratamento dos agravos resultantes da violência sexual contra mulheres e adolescentes: Norma Técnica [Internet]. Brasília; 2012 [cited 2018 Mar 29 ]. Available from: http://bvsms.saude.gov.br/bvs/publicacoes/prevencao_agravo_violencia_sexual_mulheres_3ed.pdf

3. Organización Mundial De La Salud (OMS). Resumen: Respuesta a la violencia de pareja y a la violencia sexual contra las mujeres. Directrices de la OMS para la práctica clínica y las políticas[Internet].Washington; 2014 [cited 2018 Mar 27]. Available from: http://www.who.int/ reproductivehealth/publications/violence/rhr1310/es/

4. Secretaria Nacional de Enfrentamento à Violência contra as Mulheres (BR), Secretaria de Políticas para as Mulheres da Presidência da República. Rede de Enfrentamento à Violência contra as Mulheres [Internet]. Brasília; 2011 [cited 2018 Mar 23]. Available from: http://www. spm.gov.br/sobre/publicacoes/publicacoes/2011/politica-nacional

5. Ministério da Saúde (BR), Gabinete do Ministro. Portaria n 485, de $1^{\circ}$ de abril de 2014. Redefine o funcionamento do Serviço de Atenção às Pessoas em Situação de Violência Sexual no âmbito do Sistema Único de Saúde (SUS) [Internet]. Brasília; 2014 [cited 2018 Mar 23]. Available from: http://bvsms.saude.gov.br/bvs/saudelegis/gm/2014/prt0485_01_04_2014.html

6. García-Moreno C, Hegarty K, d'Oliveira, AFL, Koziol-McLain J, Colombini M, Feder G. The health-systems response to violence against women. Lancet [Internet]. 2015[cited 2018 Sep 19];385(9977): 1567-79. Available from: https://doi.org/10.1016/S0140-6736(14)61837-7

7. Arboit J, Padoin SMM, Vieira LB, Paula CC, Costa MC, Cortes LF. Health care for women in situations of violence: discoordination of network professionals. Rev Esc Enferm USP[Internet]. 2017[cited 2018 Sep 27];51; e03207. Available from: http://dx.doi.org/10.1590/ S1980-220X2016013603207

8. Albuquerque Netto L, Moura MAV, Araújo CLF, Souza MHN, Silva GF. Social support networks for women in situations of violence by an intimate partner. Texto Contexto Enferm [Internet]. 2017[cited 2018 Sep 29]; 26 (2): e07120015. Available from: http://dx.doi. org/10.1590/0104-07072017007120015

9. Costa MC, Silva EB, Soares JSF, Borth LC, Honnef F. Rural women and violence situation: access and accessibility limits to the healthcare network. Rev Gaúcha Enferm [Internet]. 2017 [cited 2017 Sep 27];38(2):e59553. Available from: http://dx.doi. org/10.1590/1983- 1447.2017.02.59553

10. Silva EB, Padoin SMM, Vianna LAC. Women in situations of violence: limits of assistance. Ciênc Saúde Coletiva [Internet]. 2015 [cited 2018 Sep 27];20(1):249-58. Available from: http://www.scielo.br/pdf/csc/v20n1/pt_1413-8123-csc-20-01-00249.pdf

11. Bezerra JF, Silva RM, Cavalcanti LF, Nascimento JL, Vieira LJES, Moreira GAR. Conceitos, causas e repercussões da violência sexual contra a mulher na ótica de profissionais de saúde. Rev Bras Promoç Saúde [Internet]. 2016 [cited 2018 Sep 27]; 29(1):51-59. Available from: http:// periodicos.unifor.br/RBPS/article/view/4186/pdf 
12. Vieira LJES, Silva ACF, Moreira GAR, Cavalcanti LF, Silva RM. Protocolos na atenção à saúde de mulheres em situação de violência sexual sob a ótica de profissionais de saúde. Ciênc Saúde Coletiva [Internet]. 2016 [cited 2018 Sep 27];21(12):3957-65. Available from: http://dx.doi. org/10.1590/1413-812320152112.15362015

13. Cortes LF; Padoin SMM; Kinalski DDF. Instruments for articulating the network of attention to women in situation of violence: collective construction. Rev Gaúcha Enferm [Internet]. 2016 [cited 2018 Sep 27];37(esp): e2016-0056. Available from: http://dx.doi.org/10.1590/19831447.2016.esp.2016-0056

14. Dawson AJ , Rossiter C, Doab A , Romero B , Fitzpatrick L , Fry M. The emergency department response to women experiencing intimate partner violence: insights from interviews with clinicians in Australia. Academic Emergency Medicine [Internet]. 2019 [cited 2019 Jul 10]. Available from: http://dx.doi.org/10.1111/acem.13721

15. Stewart DE, Aviles R, Guedes A, Riazantseva E, MacMillan H. Latin American and Caribbean countries' baseline clinical and policy guidelines for responding to intimate partner violence and sexual violence against women. BMC Public Health [Internet]. 2015 [cited 2019 Jul 10];15:665. Available from: http://dx.doi.org/10.1186/s12889-015-1994-9

16. Vrees RA. Evaluation and Management of Female Victims of Sexual Assault. Obstet Gynecol Surv [Internet].2017 [cited 2019 Jul 10];72(1). Available from: http://dx.doi.org/10.1097/OGX.0000000000000390

17. Lettiere A, Nakano AMS. Rede de atenção à mulher em situação de violência: os desafios da transversalidade do cuidado. Rev Eletr Enf [Internet]. 2015[cited 2018 Sep 29];17(4):01-08. Available from: http://dx.doi.org/10.5216/ree.v17i4.32977

18. Garrafa V, Martorell LB, Nascimento WF. Críticas ao principialismo em bioética: perspectivas desde o norte e desde o sul. Saúde Soc [Internet]. 2016[cited 2018 Mar 29];25(2):442-51. Available from: http://www.revistas.usp.br/sausoc/article/view/118312/115858

19. Garrafa V, Porto D. Verbete: Bioética de intervención. In: Tealdi JC (Org.). Diccionario latinoamericano de bioética [Internet]. Bogotá; 2008 [cited 2018 Mar 27]. Available from: http://unesdoc.unesco.org/images/0016/001618/161848s.pdf

20. Feitosa SF, Nascimento WF. A bioética de intervenção no contexto do pensamento latino-americano contemporâneo. Rev Bioét [Internet]. 2015[cited 2018 Sep 20];23(2):277-84. Available from: http://www.scielo.br/pdf/bioet/v23n2/en_1983-8034-bioet-23-2-0277.pdf

21. Organização das Nações Unidas para a Educação, a Ciência e a Cultura Declaração Universal sobre Bioética e Direitos Humanos (UNESCO). Declaração Universal sobre Bioética e Direitos Humano [Internet]. UNESCO; 2005 [cited 2018 Mar 10]. Available from: http://unesdoc. unesco.org/images/0014/001461/146180por.pdf.

22. Minayo MCS. O desafio do conhecimento: pesquisa qualitativa em saúde. 14. ed. São Paulo: Hucitec, 2014. 407p.

23. Pinto LSS, Oliveira IMP, Pinto ESS, Leite CBC, Melo AN, Deus, MCBR. Women's protection public policies: evaluation of health care for victims of sexual violence. Ciênc Saúde Coletiva [Internet]. 2017 [cited 2018 Sep 27];22(5):1501-8. Available from: http://www.scielo.br/pdf/csc/ v22n5/en_1413-8123-csc-22-05-1501.pdf

24. Lanthier S, Du Mont J, Mason R. Responding to delayed disclosure of sexual assault in health settings: a systematic review. Trauma Violence Abuse [Internet]. 2016 [cited 2018 Sep 27];19(3):251-65. Available from: http://dx.doi.org/10.1177/1524838016659484

25. Zijlstra E, Lo Fo Wong S, Teerling A, Hutschemaekers G, Lagro-Janssen A. Challenges in interprofessional collaboration: experiences of care providers and policymakers in a newly set-up Dutch assault centre. Scand J Caring Sci [Internet]. 2017 [cited 2018 Sep 27];32(1):138-46. Available from: http://dx.doi.org/10.1111/scs.12439

26. Garrafa V. Proteção e acesso à saúde com um bem social. In: Hellmann F, et al. Bioética e saúde coletiva: perspectivas e desafios contemporâneos. Florianópolis: DIOESC, 2012.

27. Menezes PRM, Lima IS, Correia CM, Souza SS, Erdmann AL, Gomes NP. Process of dealing with violence against women: intersectoral coordination and full attention. Saúde Soc [Internet]. 2014 [cited 2018 Sep 27];23(3):778-86. Available from: http://dx.doi.org/10.1590/ S0104-12902014000300004

28. Borth LC, Costa MC, Silva EB, Fontana DGR, Arboit J. Network to combat violence against rural women: articulation and communication of services. Rev Bras Enferm [Internet]. 2018 [cited 2018 Sep 27];71(3):1287-94. Available from: http://dx.doi.org/10.1590/0034-7167-2017-0044

29. Barros LA, Albuquerque MCS, Gomes NP, Riscado JLS, Araújo BRO, Magalhães JRF. The (un)receptive experiences of female rape victims who seek healthcare services. Rev Esc Enferm USP [Internet]. 2015 [cited 2018 Sep 27];49(2):193-200. Available from: http://dx.doi.org/10.1590/ S0080-62342015000020000

30. Sit V, Stermac L. Improving formal support after sexual assault: recommendations from survivors living in poverty in Canada. J Interpers Violence [Internet] 2017[cited 2018 Apr 16];1(8862605177447761). Available from: http://journals.sagepub.com/ doi/10.1177/0886260517744761

31. Moraes DA, Maluf F, Tauil PL, Portillo JAC. Precarisation of dentistry in private healthcare: bioethical analysis. Ciênc Saúde Coletiva [Internet]. 2019 [cited 2019 Jul 10];24(3):705-14. Available from: http://dx.doi.org/10.1590/1413-81232018243.01972017

32. Parizi RRC, Albuquerque A. Desigualdade, bioética e Direitos Humanos. Rev Bioét[Internet]. 2015 [cited 2018 Sep 27];23(2):227-37. Available from: http://dx.doi.org/10.1590/1983-80422015232061 